УДК 78.071.1(470)

ORCID: 0000-0001-6817-7038

Оксана Гармель, кандидат искусствоведения, доцент, ученый секретарь Киевского института музыки им. Р. М. Глиэра, ул. Л. Толстого, 31, Киев, 01032, Украина

Oksana Garmel,

Ph.D. in Arts, Associate Professor, Scientific Secretary of R. Glier Kyiv Institute of music, 31 Lva Tolstogo St., Kyiv 01032, Ukraine

\title{
О ДРАМАТУРГИИ ВОКАЛЬНОГО ЦИКЛА «ТВОЙ ОБЛИК МИЛЫЙ» ЭДИСОНА ДЕНИСОВА
}

В статье впервые представлен анализ драматургии вокального цикла «Твой облик милый» Э. Денисова для голоса и фортепиано на стихи А. Пушкина. Отдельно изучена поэтическая драматургия цикла и акцентировано внимание на важности этого аспекта в произведении. Раскрыты особенности музыкальной стилистики вокального цикла, в которой оригинально соединены традиции романсовой лирики с индивидуальным «стилем EDS» Э. Денисова.

Ключевые слова: вокальный цикл, поэтическая драматургия, музыкальная драматургия, творчество Эдисона Денисова.

About the dramaturgy of the vocal cycle «Your Lovely Face» by Edison Denisov. The study presents the first analysis of dramaturgy in the vocal cycle « Your Lovely Face» by E. Denisov for voice and piano on poems by A. Pushkin. The poetic dramaturgy of the cycle has been studied separately and attention has been paid to the importance of this aspect. The features of musical stylistics of the vocal cycle are revealed, in which the traditions of romance lyrics with an individual Denisov's «EDS style» are originally combined.

Key words: the vocal cycle, poetic dramaturgy, music dramaturgy, Edison Denisov's creation.

Про драматургію вокального циклу «Твій образ милий» Едісона Денисова. У статті вперше представлено аналіз драматургії вокального циклу «Твій образ милий» Е Денисова для голосу і фортепіано на вірші О. Пушкіна. Окремо вивчено поетичну драматургію циклу та акцентовано увагу на важливості цього аспекту у творі. Розкрито особливості музичної стилістики вокального циклу, в якій оригінально поєднано традиції романсової лірики з індивідуальним «стилем EDS» Е. Денисова. 
Ключові слова: вокальний цикл, поетична драматургія, музична драматургія, творчість Едісона Денисова.

В творчестве каждого композитора есть жанры, которые оказываются наиболее любимыми. Среди наследия одного из выдающихся мастеров второй половины XX века Эдисона Денисова (1929-1996) особое место занимают вокальные произведения: «...я чувствую, что вокальная музыка у меня получается лучше и легче, чем инструментальная. Мне всегда хочется писать вокальную музыку...» [4, с. 15]. Работа в жанре вокального цикла была для композитора возможностью непосредственного интимного лирического высказывания, раскрытия внутреннего духовного «я», ибо по признанию Э. Денисова, все его вокальные циклы были написаны для себя, а не на заказ [2, с. 41].

Период творчества рубежа 1970-80-х годов оказался кульминационным в обращении Э. Денисова к вокальному жанру. На протяжении пяти лет (1978-1982 гг.) им было создано шесть вокальных циклов для голоса и фортепиано и два - для голоса и инструментального ансамбля. ${ }^{1}$ Поэтической основой одного из них - «Твой облик милый» стали произведения А. С. Пушкина. Важно вспомнить, что Э. Денисов в своих высказываниях о поэзии чаще всего упоминал имя А. Пушкина и с восхищением говорил о его творчестве: «B поэзии Пушкина есть, действительно, божественная красота (выделено Э. Денисовым О. Г.). Поэтому она столь проста и столь неуловима. В Пушкине есть то, что я люблю в Моцарте и Глинке - естественность и свет» [7, c. 38]. Такое возвышенное отношение к пушкинской поэзии делает несколько особенным и цикл на его слова. Кроме того, «Твой облик милый» входит в круг сочинений, которые сам Э. Денисов выделял среди своего творческого наследия, называя особенно дорогими (Реквием, концерты для скрипки с оркестром и для альта с оркестром, симфония, балет «Исповедь»). Это - музыкальные откровения души, в которых, по словам композитора «больще меня самого» [4, с. 15].

\footnotetext{
1 Это циклы: «Листья» на стихи Франциско Танцера для сопрано и струнного трио (1978), «На повороте» на стихи Осипа Мандельштама для голоса и фортепиано (1979), «Пять стихотворений Евгения Баратынского» для голоса и фортепиано (1979), «Боль и тишина» на стихи Осипа Мандельштама для сопрано, кларнета, альта и фортепиано (1979), «Твой облик милый» на стихи Александра Пушкина для голоса и фортепиано (1980), «Флоре» на стихи Аттилы Йожефа для голоса и фортепиано (1980), «На снежном костре» на стихи Александра Блока для голоса и фортепиано (1981), «Свет и тени» на стихи Владимира Соловьёва для баса и фортепиано (1982).
} 
В украинском музыковедении цикл «Твой облик милый» еще не становился предметом отдельного исследования ${ }^{1}$. И к другим произведениям Э. Денисова украинские музыковеды обращаются достаточно редко [см.: 9; 10; 14], очевидно, ввиду их насыщенного смыслового «поля» и композиторской техники, представляющей собой оригинальное явление музыки второй половины XX века. Да и в русском музыковедении при изучении особенностей камерно-вокальных циклов Э. Денисова исследователи, прежде всего, останавливают внимание на цикле «На снежном костре» на слова А. Блока как наиболее масштабном (24 номера) и вызывающем непосредственные ассоциации с циклом «Зимний путь» Ф. Шуберта [см.: 11; 12].

Актуализированный нами цикл «Твой облик милый» представляет собой образец тонкой интеллектуальной лирики Э. Денисова, где во внимательном прочтении пушкинского слова автор соединил традиции романсовой лирики XIX века с индивидуальной техникой, получившей название «стиль EDS» (Ю. Холопов). Таким образом, анализ особенностей этого цикла составляет научную новизну работы.

В сложившейся в музыковедении традиции изучения вокальных циклов наиболее часто исследуемыми оказываются вопросы драматургии, логики продвижения художественной мысли. Они всегда актуальны и востребованы, прежде всего, исполнительской практикой. Охватить цикл как единое смысловое пространство, как особую картину мира, выстроенную из отдельных миниатюр, в которых содержательные «пучки» ${ }^{2}$ слов обретают индивидуальное композиторское интонирование, есть важный этап проникновения в произведение для каждого исполнителя. Особый интерес представляют вокальные циклы, в которых композиторы уделяют значительное внимание не только музыкальному воплощению слова, но и выстраиванию собственно поэтической драматургии циклического целого, среди которых - денисовский цикл.

\footnotetext{
${ }^{1}$ Некоторые аспекты цикла «Твой облик милый» рассмотрены в статье А. Мизитовой «Вокальный триптих Э. Денисова на стихи русских поэтов», при этом автор не ставит перед собой задачу детального анализа каждого из циклов [10, с. 173].

2 Здесь предлагается вспомнить тонкое высказывание О. Мандельштама о слове в работе «Разговор о Данте»: «Любое слово является пучком, и смысл торчит из него в разные стороны, а не устремляется в одну официальную точку. Произнося „солнце”, мы совершаем как бы огромное путешествие, к которому настолько привыкли, что едем во сне. Поэзия тем и отличается от автоматической речи, что будит нас и встряхивает на середине слова. Тогда оно оказывается гораздо длиннее, чем мы думали, и мы припоминаем, что говорить - значит всегда находиться в дороге» [8, с. 174].
} 
Цель нашей статьи - проследить особенности музыкальной драматургии вокального цикла «Твой облик милый» Э. Денисова, которые обусловлены, прежде всего, поэтической драматургией, выстроенной композитором. Для этого использован метод последовательного анализа поэтического компонента вокального цикла в его содержательной динамике, выстраивании образных и лексических «линий», определяющих драматургию целого. Акцент сделан на средствах достижения целостности произведения. Также использован метод интонационного анализа, благодаря которому выявлена роль музыкальных реминисценций в интонационной драматургии вокального цикла.

Цикл «Твой облик милый» для голоса и фортепиано был написан Э. Денисовым в 1980 году1. По признанию композитора, пушкинские стихи были отобраны ещё за десять лет до этого, но «<..> написать музыку на них всё никак не мог решиться, потому что очень высоко цүенил и цүеню Пушкина. И все эти годы я никак не мог <..> найти нужный ключ, не нарушив и не разрушив музыки стихов самого Пуикина» [13, с. 264]. Решение пришло спонтанно, как озарение, и десятичастный цикл был готов в течение недели, сразу после завершения Реквиема. О таких минутах яркого творческого вдохновения композитор оставил заметку в записной книжке: «Я некоторые сочинения начинаю без всякой внутренней подготовки, и они проясняются, рождаются и становятся во время работы, другие жее сочинения („Плачи”, Скрипичный кониерт, Реквием, „Твой облик мильй”, „Пена дней”) проходят сами по себе процесс длительного внутреннего становления и интуитивного (зачастую - подсознательного) обдумыввания. Сочинения второго типа мне легче писать - они, очевидно, внутри как-то сами по себе складываются, и у меня возникает ощущение поразительной легкости сочинения: музыка возникает сама собой и я лишь успеваю ее записывать. Момент прозрения возникает, как правило, только в сочинениях второго типа. Тайные двери открываются сами собой, и я вижу то, что только мне дано за ними видеть. А может быть, моей рукой в эти минуты водит Бог. Это - те моменты, ради которых нужно жить» [7, с. 39].

\footnotetext{
${ }^{1}$ Премьера цикла «Твой облик милый» состоялась 8 декабря 1980 года в Москве в исполнении Алексея Мартынова (тенор) и Василия Лобанова (фортепиано). В 1982 году Э. Денисов создал редакцию цикла для голоса и оркестра, которая впервые прозвучала 30 октября 1984 года в Москве в исполнении Алексея Мартынова (тенор) и симфонического оркестра под руководством Геннадия Рождественского [15, с. 54, c. 67]. В статье рассматривается цикл в первой редакции.
} 
Э. Денисов обращается к широко известным стихотворениям А. Пушкина, все из которых ранее уже становились поэтической основой романсов других композиторов, и предлагает их собственное слышание. Отобранные стихотворения созданы поэтом в разное время и охватывают период с 1816 по 1830 годы:

1. Желание (1816);

2. Ты и вы (1828);

3. «Когда в объятия мои...» (1830, название в цикле Э. Денисова «Твоя улыбка»);

4. Ночь (1823);

5. «Напрасно, милый друг, я мыслил утаить..» (1819, название в цикле Э. Денисова - «Обман души»);

6. «Я пережил свои желанья...» (1821, название в цикле Э. Денисова «Одиночество); ${ }^{1}$

7. Предчувствие (1828);

8. «Всё кончено: меж нами связи нет...» (1824);

9. «Я вас любил: любовь ещё, быть может...» (1829);

10. Прощанье (1830).

Названием для всего цикла послужила фраза из стихотворения «Прощанье». Но в пушкинской фразе «...твой образ милый...» Э. Денисов заменяет второе слово на «облик», объясняя это тем, что слово «образ» не сочетается «с той музыкой, которая там написана. Слишком много mвердых согласных» [4, с. 14]. Действительно, слово «облик» звучит более легко и утончённо, а благодаря сходству со словом «лик» в нем проступает нечто неуловимое и возвышенное.

Композитор выстраивает цикл таким образом, что отдельные лирические миниатюры А. Пушкина складываются в развернутое поэтическое повествование об истории любви: от момента томительного ожидания через переживание счастливых мгновений к печальному расставанию и далёким воспоминаниям. Такая логика развертывания целого напоминает некоторые романтические циклы XIX века²

\footnotetext{
${ }^{1}$ Далее в статье при упоминании №№ 3, 5, 6 цикла будут использоваться названия, предложенные Э. Денисовым.

2 Ассоциации с циклами романтической эпохи не случайны. Э. Денисов часто среди любимых композиторов называл Ф. Шуберта и в своей записной книжке оставил такую запись: «Мне всю жизнь хочется написать свой „Зимний путь” и свою „Прекрасную мельничиху”, но я не знаю, когда я смогу это сделать» [7, с. 38]. И хотя это творческое желание была зафиксировано уже после окончания работы над циклом «Твой облик милый» (композитор вёл дневниковые записи в 1981-1984 и 1995 гг.), постоянное внутреннее стремление - «всю жизнь» - однозначно коснулось и этого произведения.
} 
Особого исследовательского внимания заслуживает то, как Э. Денисов соединяет в драматургически целостное произведение разрозненные стихотворения А. Пушкина, которые в творчестве поэта не связаны между собой. Становясь звеньями единого повествования, лирического монолога, они неожиданно обнаруживают тесную взаимосвязь и раскрываются новыми смыслами, неуловимыми при их обособленном прочтении. Композитор настолько точно сделал выбор поэзии и настолько тонко выстроил драматургию, что здесь прослеживается логика развития внутренних душевных состояний не только на уровне смены эмоций, настроений, воплощенных в каждом стихотворении, а даже на уровне лексики. Сходные поэтические обороты, попадая в различные контексты, складываются в отдельные линии нарастания чувств, движения и преображения их оттенков. Своеобразными поэтическими лейтмотивами цикла становятся слова, фиксирующие наиболее неуловимые, но важные «измерения» человеческой души - желания, мечты и любовь. Общность лексики, акцентирование внимания на определенном круге слов и выражений воспринимаются как претворение стиля речи одного человека, а отсюда - усиление монологичности произведения.

По содержанию десять поэзий складываются в несколько микроциклов, обрамленных прологом и эпилогом. Первое стихотворение «Желание» воспринимается как пролог к последующей исповеди чувств. Замедленный темп движения поэтического ряда, заданный в первой строке («Медлительно влекутся дни мои»), отсутствие внешнего действия (только «я молчу» и «я слезы лью») способствуют воплощению застывшего времени, долгого переживания горестной, томительной минуты. Здесь появляются слова-образы, которые найдут развитие в последующих стихотворениях: «несчастливая любовь» и несколько тревожные и неопределенные мечты. Благодаря последним строкам стихотворение «Желание» оказывается несколько обособленным от последующих номеров цикла: «Мне дорого любви моей мученье - / Пускай умру, но пусть умру любя!». В них воплощен отчаянный порыв без надежды на счастье и, вообще, будущее. Это момент исчерпания своих «мучений». Поэтому здесь можно говорить о функции пролога, так как душевное состояние, претворённое в поэзии, становится точкой отсчета для развития новых чувств.

Второе, третье и четвертое стихотворения («Ты и вы», «Твоя улыбка», «Ночь») образуют первый микроцикл. Его можно условно 
назвать «восхождением к счастью», где кульминационной становится поэзия «Ночь». В стихотворении «Ты и вы» происходит поистине стремительное преображение по сравнению с первым номером: «мечты безумия» становятся «счастливыми», а на смену «несчастливой любви» приходит нежное мысленное признание «как тебя люблю!».

Атмосферу тонкого трепетного чувства, как на едином дыхании, продолжает следующая лирическая миниатюра «Твоя улыбка». Ощущение единства двух стихотворений возникает благодаря тому, что они написаны в одинаковом поэтическом размере (четырехстопный ямб) и с аналогичным чередованием рифмующихся строк (а б а б). Акцентируя внимание на одном моменте-переживании, композитор делает большую купюру в стихотворении А. Пушкина (три последних строфы). Мысленное обращение «ты», появившееся во втором номере, здесь становится реально звучащим. Но «недоверчивая улыбка» возлюбленной несколько разрушает нежную идиллию.

Кульминационное проявление светлых счастливых чувств воплощено в стихотворении «Ночь». В нём опять будет несколько «ответов» на реплики предыдущих поэзий. Так, вместо «недоверчивой улыбки» теперь «глаза блистают» и «улыбаются», а на обращение «милый друг» слышен ответ «нежный друг». И в последней строке звучит признание, которое перекликается с заключительными словами стихотворения «Ты и вы». Это - момент достижения гармонии, высшего проявления чувств любви, полюсного состояния по отношению к душевным мукам, воплощенным в прологе.

Счастье оказалось лишь мгновением, и следующий микроцикл (№№ 5-8) - это нисхождение от первого разочарования к расставанию: «Обман души», «Одиночество», «Предчувствие» и «Всё кончено». По сравнению с первым микроциклом, во втором прослеживается иное взаимоотношение между стихотворениями. Если №№ 2, 3, 4 можно воспринимать как диалоги между лирическим героем и его возлюбленной, зафиксированные мгновения которых расположены в хронологическом порядке, то во втором микроцикле эти диалоги (№ 5 «Обман души» и № 8 «Всё кончено») прерываются монологами (№ 6 «Одиночество», № 7 «Предчувствие»).

В стихотворении «Напрасно, милый друг, я мыслил утаить...» («Обман души») отражён момент угасания чувства. И вновь восприятие смысла поэзии усиливается продолжением развития ведущих словобразов: после нежных признаний в «Ночи» печально звучит реплика «перестаю тебя любить», и так долго ожидающие воплощения мечты и 
желания «погасли». Их окончательное исчезновение происходит в стихотворении: «Я пережил свои желанья, я разлюбил свои мечты...» («Одиночество»). В этом монологе, наполненном горьким осознанием, происходит своеобразное замыкание круга: печальное одиночество приводит к мыслям о смерти («И жду: придет ли мой конец?»), как это было в первой поэзии «Желание». По содержанию именно здесь заканчивается история любви. «Одиночество» - это своеобразный первый финал цикла, а все последующие номера - это ряд прощаний, каждое из которых по-разному эмоционально окрашено. Слово, вынесенное композитором в шестом стихотворении в название, по сути, относится ко всем поэзиям до конца цикла, так как герой одинок.

Последующие поэзии воплощают спектр эмоций, который возникает при расставании с дорогим человеком: и драматичная буря чувств, и трагизм, и светлое воспоминание, и примирение с неизбежным.

В седьмом стихотворении «Предчувствие» (в первой и второй строфах) продолжается линия предыдущего монолога «Одиночество». Но здесь максимально сгущается, драматизируется эмоциональное состояние, что подчёркнуто в лексике - в начале строк акцентируются слова «рок», «угрожает», «непреклонность», «неизбежный» и др. Эта поэзия выделяется наибольшими масштабами в цикле и отличается ритмическим решением: тут использован хорей, а во всех остальных стихотворениях цикла - ямб. Такое акцентирование обуславливает кульминационную функцию «Предчувствия». 1 В третьей строфе монолог «модулирует» в диалог, где нежное упоминание ангела несколько смягчает жесткое драматичное звучание поэзии.

Замыкает второй микроцикл стихотворение «Всё кончено». В нём возникает смысловая арка к пятому номеру «Обман души». Это тоже диалог прощания, но уже трагический, с оттенком безысходности и невозможности возврата к прошлому. Его несколько прозаический тон ощутим из-за избегания прилагательных (только «последний» и «горестные»), основное содержание передано глаголами. А. Пушкин нашёл точный прием для воплощения состояния пустоты и обреченности: все действия, о которых упоминается в первой строфе - в прошлом («последний раз обняв», «произносил»), а глаголы будущего времени во второй строфе - с

\footnotetext{
${ }^{1}$ Отсутствие любовной лексики в стихотворении, вероятно, обусловлено историей его возникновения. Оно было создано А. Пушкиным в связи с делом, возникшим из-за распространения отрывка из его элегии «Андрей Шенье», озаглавленного кем-то «На 14 декабря», и с допросами о принадлежности ему поэмы «Гавриилиада» [1, с. 112 113]. Возможно, Э. Денисова эта поэзия привлекла именно благодаря воплощению бурных чувств смятения, тревоги и печальных предчувствий.
} 
отрицаниями («обманывать не стану», «преследовать не буду», «прошедшее $<. .>$ позабуду»). Благодаря небольшому сокращению, которое делает Э. Денисов (купирует две последние строки), смысловой акцент приходится на заключительную фразу «не для меня сотворена любовь».

Два заключительных номера - № 9 «Я вас любил» и № 10 «Прощанье» во временно́м отношении несколько отдалены от основных событий повествования. «Я вас любил» в контексте целого - это воображаемый диалог, возникающий как далёкое воспоминание. В нём возвращается надолго забытое обращение «вы» (оно исчезло из поэзии после того как «пустое вы сердечным mы она, обмолвясь, заменила» в № 2), в котором есть оттенок уважения и вместе с тем - отстраненности и отчуждения.

Последнее «Прощанье» - эпилог цикла, события которого, как и пролога, достаточно удалены во времени («Бегут меняясь наши лета, меняя всё, меняя нас»). Нежные светлые воспоминания о былых мечтах («дерзаю $<\ldots>$ будить мечту сердечной силой») сменяются окончательным прощанием: «Уж ты для своего поэта / Могильным сумраком одета, / И для тебя твой друг угас».

Таким образом, поэтическая драматургия цикла, выстроенная Э. Денисовым, имеет свои особенности. Все стихотворения тесно связаны благодаря единой линии развертывания повествования, лексическим взаимосвязям, поэтическому размеру. При этом выделяются две финальные зоны: № 5 «Обман души», где расставание предрешено, и № 10 «Прощанье» - собственно завершение цикла. Также важно отметить две кульминационные зоны: № 4 «Ночь» - лирическую, высшее проявление светлых чувств и № 7 «Предчувствие»- драматическую. Обе кульминации - это воплощение сильных эмоций, но полюсных по отношению друг к другу. В драматургии целого кульминационный акцент всё же приходится на № 7 «Предчувствие», так как он выделяется внутренним эмоциональным напряжением, активностью, масштабами и расположением в зоне золотого сечения.

В музыкальном решении цикл является удивительно цельным, монолитным. Основной принцип работы с поэтическим текстом и стилистика музыкального языка, заложенные в первом номере, прослеживаются на протяжении всего произведения, варьируясь в зависимости от содержания и места в драматургии.

Работая с поэзией, композитор всегда вносил в неё изменения. «Так было и со стихами Пушкина <...> - не потому, что они мне не нравятся, а для того, чтобы сделать эти стихи более „своими”» [4, с. 14]. Кроме двух купюр (в № 3 и № 8), Э. Денисов изменил только некоторые знаки 
препинания, причем нередко они противоречат логике ритмичного интонирования стиха и правилам пунктуации. Таким образом, композитор по-своему услышал внутренний пульс и дыхание поэзии. Но самое главное - он за поэтической формой, регулярной акцентной ритмикой услышал интонацию и фразировку прозы, разговора, монолога. Интересно заметить, что о такой необыкновенной особенности поэзии А. Пушкина писал Ю. М. Лотман: «Стихотворения Пушкина представляют наибольшую трудность для традиционного анализа <..>. Чувствуя значительность и богатство поэтического содержания текста, исследователь бессилен объяснить, в чем же состоит механизм воздействия стихотворения, почему эти, столь похожие на обычную прозу (разрядка моя - О.Г.), стихи содержат так много значений, передать которые нехудожественная речь бессильна» [3, с. 159].

Высвобождение музыкального ритма мелодии из «каркаса» стиха достигается Э. Денисовым благодаря некоторым приёмам, последовательно применяемым в цикле. Это различное ритмическое воплощение рифмующихся строк, стремление к индивидуализации ритмики каждой мелодической фразы, что иногда приводит к тотальному обновлению внутритактового ритма на протяжении всего романса (например, в № 2 «Ты и вы», № 3 «Твоя улыбка», № 6 «Одиночество»). Также композитор избегает равномерную ритмическую пульсацию, которая предполагается стихотворным размером; иногда исключает люфт-паузы между строками путем объединения в единое построение окончания строки и начала следующей. Особую роль в вокальной партии романсов Э. Денисова играют паузы, которые дробят мелодию на отдельные фразы. А так как в цикле преобладают умеренные темпы (при этом паузы часто достаточно протяжённы - четвертные, половинные), то это вносит в общую музыкальную атмосферу эффект осмысления каждого высказывания.

Общее интонационное «поле» определяет единство музыкального решения цикла. Звуковая материя произведения «сплетена» из круга подобных интонаций и оборотов (именно сплетена, так как в организации музыкальной ткани главенствует логика развертывания горизонтали, а не вертикали). Выбор интонаций обусловлен общим образным строем сочинения, стремлением воплотить в музыке особый круг состояний. Для Э. Денисова это - возвышенная созерцательность. ${ }^{1}$ «Она как бы забывает о

\footnotetext{
1 Такое определение образно-смыслового строя лирики Э. Денисова принадлежит Ю. Холопову и относится как к циклу «Твой облик милый», так и к творчеству композитора в целом [6, с. 60].
} 
приземленности быта, суеты, находится в разрыве с „пеной дней”, со всем наносным в реальной жизни. Сердцевина такой лирики - образ абсолютной очищенности и кротости, „гений чистой красоты”. Субъективно Денисов так ощущает наиболее близких ему художников Шуберта (...), Моцарта (...), Глинку (...), Пушкина» [6, с. 60]. Возвышенная созерцательность не лишена внутренней дифференциации, что предполагается содержанием стихов А. Пушкина. Эти эмоции утонченны и изысканны. Композитор стремится заполнить тот вакуум, который, по его мнению, образовался в современном искусстве: « $B$ современной музыке мне не хватает нежности, чистоты, хрупкости, свежести, прозрачности, трогательности» [4, с. 18]. Именно такими словами можно наиболее точно охарактеризовать круг музыкальных образов цикла. Они, в свою очередь, определили композиторскую технику для их воплощения.

При тесном переплетении вокальной и инструментальной партий, их интонационные сферы достаточно индивидуальны. В инструментальной партии ведущее значение принадлежит полутоновым интонациям, причем они часто обрисовывают любимый оборот-монограмму композитора EDS. Часто интонационный комплекс с полутоном становится источником более протяженной мелодической линии (в двенадцатитоновой тональности). Голоса фактуры, в которые «инкрустированы» подобные обороты, пронизывают все номера цикла. Широкое использование Э. Денисовым интонаций, вырастающих из собственной музыкальной монограммы, дало основание Ю. Холопову определить эту особенность произведений композитора 1970-80-х годов как «стиль EDS»: «Экспрессия полутона, „гемиинтонация” хорошо согласуются с коренными свойствами стиля Денисова, с его утонченностью выражения, неоромантической возвышенностью тона, любовью к нежным звучаниям. Если Веберна называют „маэстро pianissimo”, то во многих сочинениях Денисов „маэстро dolcissimo" <..>. Об этом качестве эстетической природы его стиля говорит мелодика EDS» [5, с. 84].

Мелодика вокальной партии решена в другом ключе. Пушкинские стихи повлекли за собой возникновение таких мелодических оборотов, которые могли быть написаны композитором XIX века. В них нет стилизации, они скорее воспринимаются как отголоски романсовой мелодики, услышанные композитором конца XX века. Вокальная партия романсов как бы «составлена» из отдельных коротких фраз, в которых тесно переплетаются речевые, декламационные интонации и песенно-романсовые обороты. Внутри этих фраз зачастую обнаруживается центральный тон, но 
так как в каждом обороте это - новый центр, то мелодия постоянно переключается в разные тональные «плоскости», что приводит к эффекту смены гармонической «светотени». В некоторых романсах начальные мелодические построения «укладываются» в тональность классикоромантической традиции, если их интонировать отдельно от фортепианной партии (№3 «Твоя улыбка», №4 «Ночь», №6 «Одиночество»).

В целом, при исполнении романсов возникает необыкновенное сочетание утонченности и экспрессии фортепианной партии, на фоне которой звучит собранная из «осколков» знакомых интонаций романсовая мелодия. Музыка утончённой красоты как бы озарена внутренним светом.

Идея света очень важна в эстетике Э. Денисова. Он говорил: «B музыке должно быть понятие света», «должна быть вера», «свет должен быть и в жизни» [6, с. 49]. Символическим музыкальным воплощением света для композитора становится ре мажор (как тональный центр, но чаще - как трезвучие). Такую же функцию, по словам композитора, выполняет ре мажор и в цикле «Твой облик милый».

Э. Денисов прочитывает содержание поэтического первоисточника как тонкий психолог, отражая в музыке все нюансы и повороты текста. Важной характеристикой его романсов является внутренняя диалогичность музыкального текста, которая воплощается через разное качество соотношения вокальной и фортепианной партий. Оставляя за рамками статьи последовательный интонационный анализ (ввиду его масштабности), отметим особенности отдельных романсов, определяющих контур драматургии.

В первом романсе «Желание» создан образ сосредоточенного размышления, томительного ожидания, общий повествовательный тон которого способствует неторопливости развертывания мысли. Достижение такого образа - итог взаимодействия нескольких слагаемых. Э. Денисов мыслит фактуру романса как сочетание трёх голосов - вокального и двух фортепианных. В вокальном голосе композитором найдена тонкая грань между напевными романсовыми оборотами и декламацией, что сообщает произведению черты монологичности. Контрапунктирующий фортепианный голос максимально насыщен полутоновыми оборотами с использованием монограммы EDS. Его извилистая мелодическая линия в низком регистре способствует воплощению чувства сломленности. Другой голос фортепианного пласта продолжает эту образную линию и удерживает начальное образно-эмоциональное состояние. В таком соотношении вокальной и фортепианной партии есть черты внутренней 
диалогичности, рефлексии, где первичная эмоция, идущая от содержания текста, отражается в интонациях вокальной партии, а образ, создаваемый в фортепианных голосах, раскрывает подтекст этой эмоции. Данный принцип прослеживается во всех номерах цикла, при этом происходят постоянные колебания в соотношении двух рядов («я говорю, повествую, воспринимаю» и «я - осмысляю, предчувствую») от их противопоставления к наибольшему соприкосновению.

Светлой лирической кульминацией цикла является четвёртый романс «Ночь». Это - момент достижения гармонии, возвышенного приподнятого состояния. Музыкальное решение номера необыкновенно цельное, как бы созданное на едином дыхании. Композитор многими средствами выделяет этот романс, а особенно - некой «традиционностью», которая проявляется на разных уровнях.

Важную роль в достижении единства всех музыкальных компонентов играет выбор фактурной модели фортепианной партии, неизменной для всего романса и представляющей собой характерные общеромантические фигурации с четкой опорой на трезвучие на сильной доле. Также композитор создает эффект присутствия традиционной тональности: долгий guasi-тонический органный пункт, построенный на си-бемоль мажорном трезвучии, сменяется рядом guasi-субдоминант (на сильных долях появляются трезвучия ми-бемоль мажора, до мажора, соль минора), а начало второй строфы подчеркивается возвращением органного пункта си-бемоль мажора. Фонизм этого созвучия максимально наполняет музыкальное пространство романса, и поэтому возвращение к нему или акцентирование тона си-бемоль в последующих номерах цикла будет вызывать ассоциации с романсом «Ночь».

И в других аспектах этого романса подчеркивается традиционность. Его форма приближается к куплетной. В вокальной партии декламационное начало уходит на второй план, а усиливается роль песенно-романсовых интонаций. Более ощутима стихотворная основа текста, так как Э. Денисов несколько отступает от избранного принципа воплощения поэзии, и на смену индивидуализированному ритмическому решению приходят ритмически сходные обороты в мелодии (при этом для них характерно и подобное интонационное наполнение). Таким образом, композитор стремится к музыкальной рифме.

Такое яркое воплощение мечты, которое достигнуто в романсе «Ночь», больше не повторится в цикле. Содержание последующих вокальных миниатюр - это печальный путь прощания, расставания и утраты счастья. Начиная с пятого номера «Обман души», все романсы 
написаны как бы с оглядкой назад. И поэтому очень важным драматургическим приемом становится реминисценция.

В шестом романсе «Одиночество» суть образа передается через парадоксальную противоположность вокальной и фортепианной партий. Эта миниатюра может послужить выразительным примером одновременного воплощения события и рефлексии на него.

Мелодия романса удивительно пластична, напевна, в ней преобладает кантиленность, лишь в некоторых эпизодах дополняемая декламационностью. Это один из немногих номеров цикла, в которых вокальная партия на протяжении всей первой строфы решена в одной «тональной плоскости» (с центром «ре» и преобладанием минорного наклонения). И во второй строфе смена центральных тонов мелодии достаточно неспешна. Таким образом, вокальная партия отличается особой устойчивостью и доминированием романсовых интонаций.

В инструментальном пласте раскрывается подтекст, а вернее истинное содержание, которое кроется за внешним спокойствием печального повествования голоса. Это смятение, пустота, утрата опоры. Пластике вокальной линии здесь отвечают извилистые контрапунктирующие голоса, максимально насыщенные полутоновыми интонациями, оборотами EDS. Одним из важнейших выразительных средств становится ритмическое решение. Каждая линия фортепианной партии отличается изощренностью, нерегулярностью ритмики. Наряду с чётным делением длительностей широко применяется нечётное, а в соединении голосов наблюдается их постоянная несинхронность (они звучат вместе только несколько раз на сильную долю). Благодаря такому решению композитор психологически тонко воссоздал состояние одиночества: тихое скольжение каждого из голосов романса «в своем измерении», условно не соприкасаясь, символически воплощает «разорванность» внутреннего мира героя.

Линию монолога «Одиночество» продолжает седьмой романс «Предчувствие», который несёт функцию драматической кульминации цикла. Здесь сложные внутренние переживания выплеснулись наружу как буря мрачных предчувствий. Тревожные вихревые пассажи фортепианной партии с первого до последнего такта определяют такой образный строй романса.

«Предчувствие» выделяется многими внешними признаками среди номеров цикла: самым подвижным темпом, наибольшим масштабом, общим динамическим решением $-f$ и $m f$ (до этого основной оттенок в цикле был $\rho$, а самый громкий $-m f)$, подробной микродинамикой. В 
вокальной партии немаловажную роль играют категоричные ходы на ч.5, ч.4, которые в большей мере обращают на себя внимание, несмотря на достаточную насыщенность гемиинтонациями. Особую порывистость речи придают синкопы. И в целом композитор стремится ритмически индивидуализировать каждый оборот, используя в ритмическом делении небинарный принцип пропорций $(5: 6,5: 4)$, который до этого встречался только в фортепианной партии.

Важно отметить, что в третьей строфе происходит некоторое просветление колорита, тесно связанное с содержанием поэзии обращением к ангелу. В вокальную партию проникают интонации мольбы, которые «подсвечиваются» денисовским ре мажором. Здесь возникает смысловая арка к первому романсу «Желание», где слова «О, жизни час!» звучали на фоне ре-мажорного трезвучия. Таким образом, уточняется символика созвучия Э. Денисова: в цикле оно тесно связано с выходом из суетного мира и обращением к Высокому бытию, к Вечности. Это духовное вознесение композитор тонко воплотил в окончании романса, где «ускользающие» пассажи стремительно поднимаются в высокий регистр. Их звучание при динамике $\rho \rho \rho$ напоминает флажолеты скрипок, они становятся почти невесомыми, ирреальными и, достигая крайней точки фортепианной клавиатуры $\left(\mathrm{a}^{5}\right)$, растворяются в пространстве $(\rho \rho \rho \rho)$.

В финальном романсе «Прощание» нет места мрачным образам и тягостным воспоминаниям. Заключительная вокальная миниатюра, вопреки печальным тонам поэтического текста, необыкновенно светлая и чистая. В трактовке Э. Денисова это не просто окончательное прощание, а примирение, прощение, которое приводит к внутренней гармонии, когда образ возлюбленной «превращается» в облик (лик) и становится недосягаемым идеалом вечной совершенной красоты. В этой музыке композитор стремится максимально подняться над стихией чувств, эмоций и создает образ, наполненный умиротворенной созерцательностью. Здесь преобладает светлый денисовский ре мажор, мелодизация всех фактурных голосов, насыщение их романсовыми оборотами. Волнообразное построение линии нижнего фортепианного голоса несёт черты колыбельности, баркарольности, благодаря чему создается общее спокойствие. А выразительный оборот в верхнем фортепианном голосе, который в своём контуре условно обрисовывает круг, неоднократно повторяется, становится основой многих фраз вокальной партии, чем вносит ощущение остинатности и усиливает созерцательный характер романса. 
Истоки образного и тематического решения заключительного номера - во второй строфе пятой миниатюры «Обман души», где впервые наметился итог всего цикла. Кроме этого, в «Прощании» есть ряд тонких реминисценций отдельных оборотов и музыкальных символов из предыдущих номеров. Так, лишь возникли в поэзии слова о прежних мечтах ( $7^{\text {й }}$ такт), музыкальный ряд их символически «подсвечивает»: в фортепианной партии выделяется тон «си-бемоль», который тесно связан с №4 «Ночь». Интересно решены следующие реминисценции, в которых создан эффект одновременного произнесения двух текстов - реально звучащего и мысленно интонируемого в воспоминаниях. В начале второй строфы романса («Бегут меняясь наши лета / Меняя всё, меняя нас») возвращается ре мажор, но фактурная

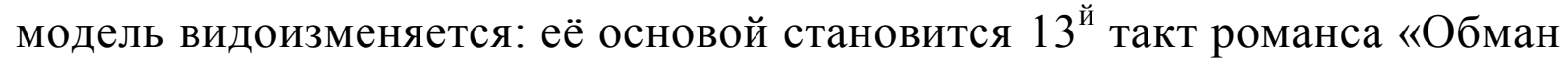
души» (в тексте - завершение фразы «Пора прекрасная прошла»). Далее $\left(18^{\text {й }}\right.$ такт) в верхний голос фортепианного пласта проникает кульминационная фраза из вокальной партии романса «Всё кончено». Благодаря этому достигается эффект одновременного произнесения двух текстов: у голоса - «Уж ты для своего поэта могильным сумраком одета», у фортепиано - «Не для меня сотворена любовь». Последняя реминисценция возникает в фортепианной постлюдии «Прощания», которая является своеобразной миниатюрной моделью всего романса. Её заключительный каданс напоминает аналогичный оборот первого номера цикла, и здесь композитор, вновь как бы безмолвно, произносит последние слова романса «Желание»: «Но пусть умру любя!».

В вокальном цикле «Твой облик милый» Э. Денисов предложил тонкое, оригинальное прочтение поэзии А. Пушкина, достигнув необыкновенной цельности в воплощении концепции произведения, созданного на основе разрозненных стихотворений. Это единство достигается на разных уровнях сочинения. На уровне поэтической драматургии это: создание стройной логики развития лирических образов; развёртывание эмоционального плана произведения вокруг концептов «желания», «мечты», «любовь»; выбор стихотворений с общими мотивами в лексике и с подобным поэтическим размером. На уровне музыкальной драматургии это: общее интонационное «поле» всех романсов (при этом насыщение вокальной партии «осколками» романсовых интонаций, а инструментальной - гемиинтонациями, мотивами с монограммой EDS); смысловое соотношение вокальной и фортепианной партий как события и рефлексии на него (в амплитуде от гармоничного соединения до контраста и сосуществования в разных 
«измерениях»); использование гармонических средств с символическим подтекстом (трезвучий си-бемоль мажора, ре мажора); «вкрапление»в фортепианную партию тематических реминисценций, создающих эффект смысловой полифонии (начиная с №5 «Обман души», в содержании которого предрешён финал) и др.

Важно отдельно отметить центральную идею музыкальной драматургии цикла. Если ещё раз охватить единым взглядом поэтический ряд, то в развёртывании повествования наблюдается чёткая сюжетная линия от возникновения мечты к ее исполнению и крушению надежд. А в музыкальной трактовке можно проследить не одно, а два «восхождения» к светлой мечте, чистому идеалу: одно совпадает с развитием сюжета (от первого номера к четвертому), а второе проявляется в конце цикла (девятый и, особенно, десятый романсы). В таком, на первый взгляд, неожиданном завершении всего цикла нашли претворение эстетические взгляды Э. Денисова, наполненные стремлением к высоким темам поиска истинной красоты и духовного совершенствования человека в его движении к Свету.

1. Вересаев В. Пушкин в жизни. Минск: Маст. літ., 1986. 685 с.

2. Катунян М. Эдисон Денисов. Настоящая музыка всегда духовна//Музыкальная академия. 1997. № 2. С. 37-42.

3. Лотман Ю. М. Анализ поэтического текста. Структура стиха. Ленинград: Просвещение, 1972. 272 с.

4. Пантиелев Г. Эдисон Денисов. «Не люблю формальное искусство...»//Советская музыка. 1989. № 12. С. 12-20.

5. Холопов Ю. Двенадиатитоновость у конща века: музыка Эдисона Денисова//Музыка Эдисона Денисова. Материаль научной конференции, посвященной 65-летию композитора. Москва: Моск. гос. консерватория им. П. И. Чайковского, 1995. С. 76-94.

6. Холопов Ю., Ценова В. Эдисон Денисов. Москва: Композитор, 1993. 312 c.

7. Ценова В. «Когда рукою водит Бог...»: Из записных книжек Эдисона Денисова//Музыкальная жизнь. 1997. № 5. С. 37-40.

8. Мандельштам О. Разговор о Данте//Мандельштам О. Избранное. Магадан: Кн. изд-во, 1990. С. 164-207.

9. Мизитова А. Смысловые обертоны конщерта для скрипки с оркестром Эдисона Денисова//Київське музикознавство. Культурологія та мистеитвознавство. $3 б$. статей. Вип. 15. Київ: КДВМУ ім. Р. М. Глієра, 2004. С. 186-194.

10. Мизитова А. А. Вокальный триптих Э. Денисова на стихи русских поэтов//Проблеми взаємодії мистеитва, педагогіки та теорії $і$ практики освіти. 36. наукових праџь. Вип. 10. Київ: Науковий світ, 2002. С. 170-180.

11. Котлярова Л. В. Э. Денисов и А. Блок: символизачия как черта творческого метода//Музыковедение: Ежемесячный научный журнал. 2009. № 5. С. 22-29. 
12. Кривопалова В. А. Интонационные особенности вокального ичикла Э. Денисова на стихи А. Блока «На снежном костре»//Вестник Томского государственного университета. 2011. № 1. С. 39-46.

13. Шульгин Д. Признание Эдисона Денисова. По материалам бесед. Москва: Композитор, 1998. 464 c.

14. Стаховская Е. Стилистические особенности камерно-вокальных произведений Э. Денисова на тексты О. Мандельштама и А. Йожефа//Музичне мистецттво $i$ культура. Науковий вісник Одеської держ. музичної академії імені A. В. Нежданової. Вип. 9. Одеса: Друкарський дім, 2008. С. 311-321.

15. Sikorski H. Edison Denisov. Sikorski Musikverlage. Hamburg, 2017. 145 p. URL: https://www.sikorski.de/media/files/1/12/1014/1031/.../denisov_werkverzeichnis.pdf (дата обращения: 02.07.2018).

\section{References}

1. Veresaev, V. (1986). Pushkin v zhizni. Minsk: Mast. lit., 685 s.

2. Katunyan, M. (1997). Edison Denisov. Nastoyaschaya muzyika vsegda duhovna. Muzyikalnaya akademiya, \#2, S. 37-42.

3. Lotman, Yu. (1972). Analiz poeticheskogo teksta. Struktura stiha. Leningrad: Prosveschenie, 272 s.

4. Pantielev, G. (1989). Edison Denisov. «Ne lyublyu formalnoe iskusstvo...». Sovetskaya muzyika, №12, S. 12-20.

5. Holopov, Yu. (1995). Dvenadtsatitonovost u kontsa veka: muzyika Edisona Denisova. Muzyika Edisona Denisova. Materialyi nauchnoy konferentsii, posvyaschennoy 65-letiyu kompozitora. Moskva: Mosk. gos. konservatoriya im. P. I. Chaykovskogo, S. 76-94.

6. Holopov, Yu. and Tsenova, V. (1993). Edison Denisov. Moskva: Kompozitor, $312 \mathrm{~s}$.

7. Tsenova, V. (1997). «Kogda rukoyu vodit Bog...»: Iz zapisnyih knizhek Edisona Denisova. Muzyikalnaya zhizn, №5, S. 37-40.

8. Mandelshtam, O. (1990). Razgovoro Dante. O. Mandelshtam. Izbrannoe. Magadan: Kn. izd-vo, S. 164-207.

9. Mizitova, A. (2004). Smyislovyie obertonyi kontserta dlya skripki s orkestrom Edisona Denisova. Ky yivs ’ke muzy Koznavstvo. Kul 'turologiya ta my `stecztvoznavstvo. Zb. statej. Vy'p. 15. Ky'yiv: KDVMU im. R. M. Gliyera, S. 186-194.

10. Mizitova, A. (2002). Vokalnyiy triptih E. Denisova na stihi russkih poetov. Problemy' vzayemodiyi my stecztva, pedagogiky 'ta teoriyi i prakty 'ky`osvity`. Zb. naukovy x pracz`. Vy'p. 10. Ky'yiv: Naukovy ’ svit, S. 170-180.

11. Kotlyarova, L. (2009). E. Denisov i A. Blok: simvolizatsiya kak cherta tvorcheskogo metoda. Muzyikovedenie: Ezhemesyachnyiy nauchnyiy zhurnal, №5. S. 22-29.

12. Krivopalova, $V$. (2011). Intonatsionnyie osobennosti vokalnogo tsikla E. Denisova na stihi A. Bloka «Na snezhnom kostre». Vestnik Tomskogo gosudarstvennogo universiteta, №1, S. 39-46.

13. Shulgin, D. (1998). Priznanie Edisona Denisova. Po materialam besed. Moskva: Kompozitor, $464 \mathrm{~s}$.

14. Stahovskaya, E. (2008). Stilisticheskie osobennosti kamerno-vokalnyih proizvedeniy E. Denisova na tekstyi O. Mandelshtama i A. Yozhefa. Muzy 'chne my stecztvo i kul tura. Naukovy j visny`k Odes koyi derzh. muzy`chnoyi akademiyi imeni A. V. Nezhdanovoyi. Vy'p. 9. Odesa: Drukars 'ky j dim, S. 311-321.

15. Sikorski H. Edison Denisov. Sikorski Musikverlage. Hamburg, 2017. 145 p. [online] Available at: https://www.sikorski.de/media/files/1/12/1014/1031/.../denisov_werkverzeichnis.pdf [Accessed 02 july 2018]. 